\title{
Teaching reading through cornell notes strategy
}

\author{
Susnifa Atun Sholikhah ${ }^{1}$, S Sumani ${ }^{1}$, and Brigitta Septarini Rahmasari ${ }^{1}$
}

${ }^{1}$ English Education Department, Universitas PGRI Madiun, Indonesia

\begin{tabular}{l}
\hline \hline Article Info \\
\hline Article history: \\
Received Aug 12, 2019 \\
Revised Sept 8, 2019 \\
Accepted Sept 26, 2019
\end{tabular}

\section{Keywords:}

Cornell Notes Strategy;

Reading Skill

\begin{abstract}
The purposes of the research are to describe the implementation, advantages and disadvantages, and solution from disadvantages of teaching reading by using Cornell Note strategy. The research uses descriptive qualitative research as approach and type of research. The sources of data are social situation, participant, and document. The techniques of collecting data are observation, interview, and documentation. To know the validity of the data, the researcher uses methodology triangulation. The technique of data analysis are data condensation, data display, conclusion and verification.The result of the research shows that the implementation of Cornell Note strategy has three steps included pre-activity, whilst- activity, and post- activity. The pre-activities include greeting, praying, checking students' attendence and explaining the purpose of the meeting. The whilst- activities, the teacher explains how the procedures to read the text by using Cornell Note strategy. The procedures are prepare the worksheet, takes note in right column, write the question in left column, summarize information in bottom space, recite the note. Lastly, post- activities include reviewing and making resume of the material. The advantages are; first, can help the students to analyze the important information in the text. Second, motivate to read a text. Third, train the students' concentration. Lastly, make the students enjoy in learning reading. Meanwhile, the disadvantages are; first, the students are difficult to know the meaning of the word in the text and make the question with correct structure into English. Besides, the solutions for the disadvantages of implementation Cornell Note strategy are; first, the teacher gives axamples the students to make a simple question. Second, the students can search a difficult word in the dictionary. In this research, the researcher also gives suggestions for the teacher, students, the school and the onther researchers.
\end{abstract}

Copyright (c) 2019 Department of English Teaching. All rights reserved.

Corresponding Author:

Susnifa Atun Sholikhah

English Education Department, Universitas PGRI Madiun, Indonesia

Jalan Setiabudi No. 85 Madiun

Email: nifasholikhah@hahoo.com

\section{Introduction}

Reading is the essential skill in teaching and learning process. Reading make students more comprehend when they read the text. The students also get important informations from reading. Nunan (2003:69) states that reading is essential skill for learners of English as a second language. For most of these learners it is the most important skill to master in order to ensure succes not only in learning English, but also in learning any content class where reading in English is required. The interesting class include the media, methods, or strategies that can be used by the teacher. Based on the observationat 7A students of SMP N 1 Jiwan the reseacher finds some problems in reading. First, the students get difficulty to comprehend the text because they have very limited vocabulary so that they cannot answer the questions from their teacher related with the text. Second, students still ask the meaning of some words that they do not know to the teacher. It is 
impacted to need more times to read a text. Then, students have difficulties in sharing the information, identifying information, topic, and main idea of the text. Then, there are some students who are passive and lack of motivation in learning reading. Besides, not only from the students, the problems also come from the teacher. The teacher usestraditional teaching method or technique and the teacher does not use media in learning English. The teacher gives reading texts and gives broad oral explanation without discussion. Cornell notes is one of the strategies that can be used in the teaching reading process. This strategy encourages the students to read a text and create a summary about the topic. According to Pauk (2001: 238) "The cornell note-taking system is more than a sheet of paper on which to take notes". Meanwhile, according to MCKnight (2010: 76) "Cornell note is a widely used and accepted strategy for taking notes. The students should take notes in the right-hand column of the organizer; the left-hand column is for responding questions, main points, or ideas. The bottom space prompts students to summarize the information they have recorded". Meanwhile, based on the Rosalina's ressearch with title The Effect Of Using Cornell Notes Strategy On The Students' Reading Comprehension: An Experimental Research At Tenth Grade Students Of SMA Muhammadiyah 3 Jember show that the result of applying cornell notes strategy has significant effect in the form of improvement of students' reading comprehension of the tenth grade students at SMA Muhammadiyah 3 Jember. It shows that the value of control class is 77 and the experimental class is 83 . It means, the value of control class is higher than experimental class. So, this research is relevant to solve the problem of the research. The teacher wants to solve the problem of teaching reading especially in SMP N 1 Jiwan Madiun by using Cornell Notes strategy by doing research in entiled "Teaching reading through Cornell notesat seventh grade students of SMP N 1 Jiwan.

\section{Method}

In this research, the researcher uses qualitative research. The subject of this reasearch are students seventh grade of class A at SMPN 1 Jiwan. They are consist of 12 male and 10 female.

The techniques of collecting data are observation, interview, and documentation. To know the validity of the data, the researcher uses methodology triangulation. The technique of data analysis are data condensation, data display, conclusion and verification.

\section{Finding and Discussion}

After having the research, the reseracher finds the data which are gotten through observation, interview, and documentation. The Implementation of Cornell Note Strategy in Teaching Reading for Seventh Grade of SMP n 1 Jiwan Madiun in the Schooling Year of 2016/ 2017. First, pre- Activities, n the pre-activities, firstly the teacher greets the students before starting the lesson. Secondly, the teacher asks one of the student to led prayer together in front of the class. Then, the teacher asks who is absent today. After that, the teacher explains the purpose of the material in the meeting that is about text.Second, whilstActivities.First, the teacher explains about descriptive text and explains how to read the text by using Cornell Note strategy. Then, the teacher gives a text about the description of Joko Widodo and worksheet of Cornell Note to the students. Then, the teacher asks the students to read the text during ten minutes. Second, the teacher asks the students to fill up the note colomn with paragraph based on what they read. Third, the teacher asks the students to move in question colomn or cue column to write question based on what the students write in the note column. Fourt, the teacher asks the students to write summary based on they write in note column and question column. Fifth, the teacher asks the students to answer the question based on they write in note column. Before it, they have to close note column. The last activities, the teacher asks one of the students to read her work. Here, teacher and students discuss the students' answer in Cornell Note worksheet if it is correct or not based on the text. After that, teacher asks other students to give response about it. Next, teacher and students concluded the content of descriptive text. Third, post- Activities. In the post-activities, the teacher and students review and make resume of the material. Then the students pay attention. After that, the teacher asked students' difficulties during reading class by using Cornell Note strategy, then the students give response by saying that all students have no difficulties. Finally, the teacher close the meeting.

English Teaching Journal, Vol. 7, No. 2, Desember 2019: $75-78$ 
Besides, there are some advantages and disadvantages of using Cornell Note strategy in teaching reading for seventh grade of SMP N 1 jiwan madiun. They are as follows: 1)The students are able to analyze the important information in the text. The students are motivate to read a text by using Cornell Note strategy. Therefore, the students like reading by using the strategy, 2) Cornell Note strategy trains the students' concentration. The lastly, 3)Cornell Note strategy make the students enjoy in learning reading.

Meanwhile, there are some disadvantages of using Cornell Note strategy in teaching reading for seventh grade of SMP N 1 Jiwan Madiun. The disadvantages are: 1) The students with poor vocabulary are difficult to know the meaning of word in the text.2) The students with poor knowledge are difficult to make the question with correct structure into English.

Then, there are some solutions for disadvantages of using Cornell Note strategy in teaching reading for seventh grade of SMP N 1 Jiwan Madiun. The solutions are : 1) The students search a difficult word in the dictionary . 2) The teacher gives examples the students to make a simple question.

The researcher discuss about the result of implementation of Cornell Note strategy for seventh grade students of SMP N 1 Jiwan Madiun in the schooling year of 2016/ 2017. Firtsly, there are some steps in implementation of Cornell Note strategy: first, in pre- activities the teacher greet the students before starting the lesson. Then, the teacher asks one of the students to lead prayer together in front of the class. After that, the teacher check the students' attendanlist. The last activity in pre-activity is the teacher explains the purpose of the material in the meeting that was about the text. It is supported with theory from Hughes and Moate (2007: 2) In- pre activity there are some steps: 1) entering the classroom, 2) Every day greeting, 3) meeting a new class, 4) taking the register, 5) dealing with lateness. Second is whilst activities, in this activity the researcher do some activities. First, the teacher explains about descriptive text and explains how to read the text by using Cornell Note strategy. Then, the teacher gives a text about the description of Joko Widodo and worksheet of Cornell Note to the students. Then, the teacher asks the students to read the text during ten minutes. Second, the teacher asks the students to filling up the note colomn with paragraph based on what they read. Third, the teacher asksthe students to move in question colomn or cue column to write question based on what the students write in the note column. Fourt, the teacher asks the students to write summary. Fifth, the teacher asks the students to answer the question based on they write in note column. The last activities, the teacher asks one of the students to read her work. It is supported with the theory from Ellis, D. B (2009: 155- 156) defines precedures of Cornell Note strategy are as follows: 1) Format your paper, 2) Takes notes, leaving the cue column blank, 3) condense your notes in the cue column, 4) write a summary, 5) use the cue column to recite. The last activity is post- activities. In this activity the teacher and students reviewed and made resume of the material. Finally, the teacher closed the meeting and says good bye to the students. It is suitable with the checklist of observation and lesson plan (RPP). Secondly, the reseacher concludes the result of advantages and disadvantages of the teaching reading through Cornell Note strategy that suitable with the observation, interview, documentation, and supported with the theory of Pauk (2001: 250-251). Thirdly, the reseacher concludes the result of conclusion for disadvantages of the teaching reading through Cornell Note strategy that suitable with the observation, interview, documentation.

\section{Conclusion}

Based on the disscusion in chapter $\mathrm{V}$, the implementation of teaching reading by using Cornell Note strategy for seventh grade students of SMP N 1 Jiwan Madiun in the schooling year 2016/ 2017 has three steps included pre-activty, whilst-activity, and post- activity. The implementation is suitable with checklist observation, lesson plam (RPP), and theory of Ellis, D. B (2009; 155-156).

There are some advantages of teaching reading by using Cornell Note strategy for the seventh grade students of SMP N 1 Jiwan Madiun in the schooling year 2016/2017. They are; first, the strategy helps students to analyze the important information in the text so they can understand the content of the text easily. Second, the students are interested to read a text by using the strategy. Third, the strategy trains the students' concentration. Fourt, the students enjoy in learning reading.

Meanwhile, the disadvantages of teaching reading by using Cornell Note strategy for seventh grade students of SMP N 1 Jiwan Madiun in the shcooling year 2016/ 2017 are; first, it takes long time because the teacher always guides step by step to complete the column in Cornell Note worksheet. Second, the students 
with poor vocabulary aredifficult to know the meaning of the word in the text. Third, the students are difficult to make the question with correct structure into English.

Besides, the solutions for disadvantages of teaching reading by using Cornell Note strategy for seventh grade students of SMP N 1 Jiwan Madiun in the schooling year 2016/ 2017 are the first, the students search a difficult word in the dictionary when they are find a difficult word in the text. Second, the teacher gives examples the students to make a simple question. Third, the teacher is able to manage time so it is does not require long time during the learning process.

\section{References}

Alderson, J. C. (2001). Assessing Reading. Cambridge University Press.

Arikunto, Suharsimi. (2010). Prosedur Penelitian Suatu Pendekatan Praktik. Jakarta: Rineka Cipta.

Artono Wardiman DKK. (2008). English in Focus. Jakarta: Pusat Perbukuan.

Berg, B. L. (2001). Qualitative Research Methods for the School Sciences. Boston: Allyn and Bacon.

Bogdan, R. C., and Biklen, S. K. (2009). Qualitative Reserach for Education an Introduction Theories and Methods. US: Pearson Education, Inc.

Brown, H. Douglas. (2001). Teaching by Principles An Interactive Approach to Language Pedagogy. San Francisco: Addison Wesley Longman Inc.

Cahyono, B. Y. (2009). Techniques in Teaching EFL Writing. 2009. Malang: State University of Malang Press.

Cahyono, B. Y., and Mukminatien, N. (2011). Techniques and Strategies in Enhance English Language Learning. Malang: State University of Malang Press.

Cresswell, J. W. (2003). Research Design Qualitative, Quantitative, and Mixed Methods Approaches Second Edition. California: Sage Publication Inc.

Davoudi, M., Moattarian, N., \& Zareian, G. (2015). The Impact of Cornell Note- Taking Method Instruction on Grammar Learning of Iraian EFL Learners (Online). (http://dx.doi.org/10.5296/jse.v5i2. 6874. Download. March, 15th 2015).

Ellis, D. B. (2009). Becoming a Master Student: Concise. Boston Houghton Mifflin.

Fraenkel, et.al. (2012). How to Design and Evaluate Research in Education. New York: McGraw- Hill.

Grabe, W.,\& Stoller, F. L. (2002). Teaching and Researching Reading. Harlow: Longman.

Khotari, C. R. (2004). Research Methodology: Methods and Techniques. New Dehli: New Edge International (P).

Laura, R. M. (2008). A Teacher's Guides to the Signet Clessics Edition of Henrik Ibsen's A Doll's House. New York: McGraw- Hill.

Maykut, P., \& Richard, M. (2005). Begining Qualitative Research a Philosophic and Practical Guide. Francis e-Library: The Falmer Press.

Miles, M. B., Huberman, A. M., and Saldana, J. (2014). Qualitative Data Analysis: A Methods Sourcebook. United States of America: Sage Publication.

Mcknight, K. S. (2010).. The Teacher's Big Book of Graphic Organizers: 100 Reproducible Organizers that Help Kids with Reading, Writing, and the Content Areas San Fransisco, CA: Jossey- Bass.

Nunan, D. (2003). Practical English Language Teaching. New York: McGraw- Hill/ Contemporary.

Patel, M., F., and Jain, Preven, M. (2008). English Language Teachin ( Methods, Tool \& Techniques). Japur: Sunrise Publiser \& Distributors.

Pauk, W. (2001). How to Study in Collage. Boston, M. A. : Houghton Mifflin

Richard, Jack C, and Renandya, Willy A. (2002). Methodology in Language Teaching. United Stated of America. Cambridge University Press. 